\title{
“Siapa yang Lebih Terampil Mengelola Konflik Rumah Tangga?" Perbedaan Manajemen Konflik Awal Perkawinan Berdasarkan Gender
}

\author{
Bidayatul Hidayah* \& Sugeng Hariyadi \\ Fakultas Ilmu Pendidikan, Universitas Negeri Semarang, Semarang
}

\begin{abstract}
Abstrak
Lima tahun awal perkawinan adalah masa yang rawan dimana pasangan suami istri sering kali mengalami konflik karena proses penyesuaian diri. Dalam hal ini, manajemen konflik rumah tangga sangat dibutuhkan. Salah satu faktor yang memengaruhi manajemen konflik rumah adalah perbedaan gender. Penelitian ini bertujuan untuk mengetahui perbedaan manajemen konflik suamiistri berdasarkan gender. Partisipan terdiri dari 182 pasangan suami istri di Semarang dengan teknik Multiple Stage Sampling. Manajemen konflik diukur dengan skala yang disusun berdasarkan manajemen konflik yang diutarakan Pruitt dan Rubin. Hasil penemuan ini menemukan bahwa terdapat perbedaan kemampuan manajemen konflik yang signifikan antara perempuan dan laki-laki. Perempuan memiliki kemampuan manajemen konflik perkawinan yang lebih baik daripada yang dimiliki laki-laki. Hal ini dapat dijelaskan oleh penelitian sebelumnya yang menyebutkan dari segi peran gender, perempuan memiliki kemampuan membina hubungan interpersonal yang lebih baik daripada laki-laki.
\end{abstract}

Kata kunci: manajemen konflik, konflik awal perkawinan, gender

\begin{abstract}
The first five years of marriage is a vulnerable period where couples often experience tensions and conflicts because they are in adjustment process. Under this circumstance, couple needs to develop conflict management skills. One factor that influence the ability to manage conflicts is gender. This study aims to examine whether the ability to manage conflict varies in terms of gender. We employed 182 married couples in Semarang as participants. We used conflict management scale as developed by Pruitt and Rubin (2009). The result shows a significant difference of conflict management between men and women. That is, women had better household conflict management skills than men. This finding might be attributed to previous research which suggest that women are better in maintaining interpersonal relationship than men.
\end{abstract}

Keywords: conflict management, early marriage conflict, gender

\section{Pendahuluan}

Perkawinan membentuk komitmen emosional yang legal yang sangat penting dalam kehidupan orang dewasa (Dildar, Bashir, Shoaib, Sultan, \& Saeed, 2012). Pasangan pada perkawinan lima tahun pertama sering kali mengalami ketegangan emosional, konflik dan perpecahan karena pasangan dalam proses menyesuaikan diri (Pudjiastuti \& Santi, 2012). Penyesuaian diri dibutuhkan karena pengalaman bersama belum banyak sehingga disebut sebagai era kritis (Dewi \& Sudhana, 2013) dan mengakibatkan timbulnya berbagai masalah (Doss, Rhoades, Stanley, \& Markman, 2009). Pada periode ini, suami istri biasanya harus melakukan penyesuaian satu sama lain, terhadap anggota keluarga dan teman masingmasing. Pada saat penyesuaian terjadi, sering timbul ketegangan emosional dan ini dipandang sebagai periode badai keluarga muda (Hurlock, 1980). Sebagian besar masalah pada masa itu adalah ekonomi dan adaptasi pasangan suami-istri dengan keluarga besar (Saidiah \& Julianto, 2016).

Pengadilan Agama di seluruh Indonesia mencatat tren perceraian didominasi oleh perselisihan dan masalah ekonomi sebagai sebab utamanya (Hidayat, 2018). Data Kementerian Agama RI, menyebutkan bahwa terdapat peningkatan perceraian dari tahun ke-tahun (Takariawan, 2015). Hampir 80\% kasus perceraian terjadi di usia pernikahan di bawah lima tahun (Hapsari, 2013; Yasmine, 2017). Salah satu penyebab perceraian adalah adanya perselisihan yang tidak terselesaikan yang membuat pasangan merasa hubungan mereka tidak lagi harmonis (Nurhasanah, 2017; Santrock, 2012). Dalam menghadapi masa itu, hal yang terpenting adalah cara pasangan Suami-Istri bersikap 
menghadapi konflik dan mengelola konflik dengan sebaik-baiknya (Nurcahyanti, 2010). Cara individu dalam mengelola konflik rumah tangga ini disebut dengan manajemen konflik perkawinan.

Manajemen konflik perkawinan adalah kemampuan individu untuk mengelola konflikkonflik yang dialaminya dengan cara yang tepat, sehingga tidak menimbulkan komplikasi negatif pada kesehatan jiwanya maupun keharmonisan keluarga (Rachmadani, 2003). Manajemen konflik dapat dilihat melalui aspek kemampuan melihat seutuhnya konflik yang terjadi, kemampuan menganalisis konflik, dan kompromi (Pruitt \& Rubin, 2009). Kerja sama individu dalam menangani konflik rumah tangga diharapkan dapat mengurangi efek dari konflik rumah tangga itu sendiri (Zhou \& Buehler, 2017).

Faktor yang memengaruhi kemampuan manajemen konflik antara lain faktor situasional dan faktor pribadi. Faktor situasional meliputi persoalan dan hubungan pribadi sedangkan faktor pribadi salah satunya dipengaruhi oleh jenis kelamin atau gender (Sari \& Widyastuti, 2015). Gender adalah perbedaan yang terkait dengan kesetaraan sosial antara pria dan wanita, didasarkan pada pengakuan bahwa perbedaan pria dan wanita disebabkan oleh perbedaan sikap dan perlakuan (Fitriyani, 2013). Ciri yang membedakan laki-laki dan perempuan tidak hanya terdapat pada fisiknya saja (Astuti, 2009), perbedaan tersebut menyebabkan perbedaan pula pada pola tingkah laku laki-laki dan perempuan (Wirawan, 2010; Sari \& Widyastuti, 2015).

Konflik di dalam rumah tangga dipengaruhi oleh perbedaan gender dalam hal perbedaan ketertarikan, pendapat dan perspektif diantara suami dan istri (Delatorre \& Wagner, 2018). Ada perbedaan tentang bagaimana cara laki-laki dan perempuan dalam menangani konflik (Dildar \& Amjad, 2017). Studi menemukan baik laki-laki ataupun perempuan cenderung menggunakan strategi manajemen konflik sesuai peran gender yang diharapkan (Gbadamosi, Ghanbari Baghestan, \& Al-Mabrouk, 2014). Bagaimanapun pula, jika manajemen konflik yang dipakai keduanya dalam mengelola konflik rumah tangga itu positif dan dapat berjalan dengan baik, maka akan berpengaruh juga dengan upaya mempertahankan rumah tangga, meningkatnya kepuasan pernikahan dan kesehatan keluarga (Delatorre \& Wagner, 2018).

Penelitian mengenai perbedaan manajemen konflik berdasarkan gender banyak dilakukan di bidang industri dan organisasi. Penelitian di bidang tersebut menemukan bahwa manajemen konflik yang baik dibutuhkan dalam produktivitas kerja. Perempuan menggunakan gaya manajemen konflik kolaboratif serta lebih produktif sedangkan laki-laki cenderung menggunakan gaya manajemen konflik yang menghindar serta lebih distruptive (Brahnam, Margavio, Hignite, Barrier, \& Chin, 2005). Penelitian sebelumnya tentang manajemen konflik dilakukan dalam konteks perusahaan atau organisasi yang hasilnya manajemen konflik yang menghindar dapat menurunkan kepuasan keja dan performa individu (DeChurch, Mesmer-Magnus, \& Doty, 2013).

Penelitian tentang perbedaan manajemen konflik berdasarkan gender dalam relasi perkawinan menemukan bahwa dalam menjalin sebuah hubungan, studi menemukan laki-laki dan perempuan akan lebih merasa puas dengan diri dan pasangannya ketika menggunakan manajemen konflik yang kolaboratif (Greff \& de Bruyne, 2000). Sementara itu, manajemen konflik menghindar tidak akan menyelesaikan konflik (Bear, Weingart, \& Todorova, 2014). Manajemen konflik yang menghindar merupakan kecenderungan untuk menghindari konfrontasi dengan berpura-pura bahwa konflik itu tidak terjadi atau mengabaikan konflik. Selain itu penelitian menemukan bahwa lakilaki mempunyai kecenderungan untuk berkhianat lebih tinggi dari perempuan (Bogda \& Sendil, 2012), kecenderungan berkhianat pada pasangan adalah salah satu indikasi manajemen konflik yang negatif. Sedangkan di satu sisi penggugat cerai kebanyakan adalah perempuan daripada laki-laki (Nurhasanah, 2017; Muharajah, 2018; Muhyiddin, 2018) karena menurut mereka perceraian adalah jalan keluar untuk menghindari stres dan depresi dalam rumah tangga (Nurhasanah, 2017). Perceraian mengindikasikan manajemen konflik yang negatif yang terjadi disebabkan ketidakmampuan individu dalam mengelola konflik dan hubungan satu sama lain (Muhyiddin, 2018).

Meski penelitian sebelumnya telah mencoba memahami perbedaan manajemen konflik pada lakilaki dan perempuan, sepengetahuan kami belum ada penelitian yang mencoba memahaminya secara spesifik pada pasangan dengan usia perkawinan yang relatif baru, yaitu lima tahun pertama. Penelitian ini dilakukan untuk mengisi kekosongan tersebut. Pengumpulan data dilakukan di kota Semarang. Semarang tercatat sebagai kota dengan perceraian tertinggi se-Indonesia pada tahun 2016 serta menempati 3 peringkat teratas kota dengan paling banyak perceraian periode 2015-2017 (Muhibar, 2016; Hidayat, 2018). Oleh karena itu, penelitian ini merupakan penelitian replikasi yang berupaya memahami apakah perbedaan gender dalam mengelola konflik rumah tangga juga ditemukan pada konteks usia perkawinan muda di kota dengan angka perceraian yang tinggi.

\section{Metode Penelitian}

\section{Partisipan}

Partisipan dalam penelitian ini adalah 91 pasangan suami-istri $(n=182)$ dengan usia perkawinan dibawah 5 tahun $(M=3,6, S D=1,22)$. Partisipan dipilih dengan teknik multiple stage cluster sampling dengan kriteria: Individu baik itu pria maupun wanita, sudah menikah secara sah, tinggal dalam satu rumah dengan pasangan, bukan janda maupun duda, dan usia perkawinan 1 sampai 5 tahun. 


\section{Alat Ukur}

Penelitian ini menggunakan alat ukur berupa skala manajemen konflik yang disusun berdasarkan aspek manajemen konflik yang disusun oleh Pruitt dan Rubin (2009) dengan modifikasi item pernyataan sesuai konteks manajemen konflik dalam rumah tangga. Skala terdiri dari 3 aspek yaitu:

Pertama, kemampuan melihat seutuhnya konflik yang terjadi. Kemampuan ini ditandai dengan indikator perilaku seperti menyadari perubahan sikap pihak lain (contoh item: "Mudah bagi saya menyadari situasi ketika ada kesalahpahaman dengan pasangan"); dan mengetahui sebab konflik (contoh item: "Saya mengetahui dengan pasti apa yang menyebabkan saya dan pasangan berkonflik").

Kedua, kemampuan menganalisis konflik. Kemampuan menganalisis konflik ditandai dengan indikator perilaku seperti mampu introspeksi diri (contoh item: "Ketika ada permasalahan dengan pasangan, saya berusaha menemukan kesalahan yang mungkin saja saya lakukan"); mampu mengoreksi pihak lain dalam berkonflik (contoh item unfavorable: "Menurut saya pasangan saya termasuk orang yang suka mendramatisi masalah"); mampu menganalisis situasi (contoh item : "Ketika saya menghadapi permasalahan dengan pasangan, saya belajar menyelesaikannya dari permasalahan yang sama yang pernah terjadi dulu").

Ketiga, kompromi. Kompromi ditandai dengan indikator perilaku seperti Musyawarah (contoh item: "Saya merasa pasangan saya perlu tahu segala permasalahan yang saya hadapi"); Keinginan untuk menyelesaikan konflik (contoh item: "Lebih penting bagi saya untuk mencari pemecahan masalah dengan suami/istri daripada menyalahkan satu sama lain"); Menerima penilaian dari pihak lain dalam konflik (contoh item: "Saya merasa perlu berubah ketika pasangan mulai terganggu dengan sikap saya").

Total keseluruhan item pada skala kemampuan manajemen konflik ini adalah 20 item dengan 5 pilihan jawaban skala (1= sangat tidak sesuai, 5= sangat sesuai). Skala disusun dengan persebaran 11 item favourable dan 9 item unfavourable. Pengujian reliabilitas dengan menggunakan teknik statistik Alpha Cronbach diperoleh hasil bahwa skala manajemen konflik rumah tangga memiliki koefisien reliabilitas cukup tinggi $(\alpha=0,67)$.

\section{Hasil Penelitian}

Gambaran manajemen konflik perkawinan secara umum dan spesifik berdasarkan aspek manajemen konflik Pruitt dan Rubin (2009) dapat dilihat pada Lampiran 1. Selanjutnya, untuk perbandingan manajemen konflik rumah tangga jika dilihat tiap aspek dapat diketahui bahwa aspek manajemen konflik yang memiliki mean empiris tertinggi diantara aspek lainnya adalah aspek kemampuan menganalisis konflik yang dimiliki individu (lihat tabel 1). Uji asumsi homogenitas didapatkan nilai $p=0,004$ atau tidak homogen, oleh karena itu dilakukan uji normalitas dan di dapat hasil $p>0,05$ maka data berdistribusi normal.

Tabel 1. Perbandingan mean tiap aspek manajemen konflik

\begin{tabular}{lll}
\hline $\begin{array}{l}\text { Manajemen konflik } \\
\text { perkawinan }\end{array}$ & Mean & $S D$ \\
\hline $\begin{array}{l}\text { Melihat seutuhnya } \\
\text { konflik yang terjadi }\end{array}$ & 18,64 & 2,75 \\
$\begin{array}{l}\text { Mampu menganalisis } \\
\text { konflik }\end{array}$ & 30,2363 & 3,50 \\
Kompromi & 23,8242 & 3,22 \\
$\quad$ Total & 72,70 & 6,48 \\
\hline
\end{tabular}

Dari perbedaan mean manajemen konflik rumah tangga, mean kelompok perempuan lebih besar dari kelompok laki-laki (lihat tabel 2). Hal ini berarti bahwa perempuan mempunyai kemampuan manajemen konflik rumah tangga lebih baik daripada laki-laki. Perempuan memiliki kemampuan lebih dalam menganalisis konflik yang terjadi dalam rumah tangganya yaitu dengan cara mengintrospeksi diri, mampu menempatkan dan mengoreksi perilaku diri dan pasangan, serta mampu menganalisis situasi saat terjadi konflik dengan pasangan. Semakin tinggi kemampuan dalam menganalisis konflik menunjukkan semakin baik pula kemampuan manajemen konflik perkawinan yang dimiliki individu. Hasil analisis uji beda dengan menggunakan T-Test Two Independent Sample diketahui terdapat perbedaan manajemen konflik yang signifikan antara perempuan $(M=73,67$, $S D=5,61)$ dan laki-laki $(M=71,73, \quad S D=7,13)$, $t(180)=2,02, p<0,05$.

Tabel 2. Hasil analisis uji T-test Two Independent Sample

\begin{tabular}{llcccc}
\hline & Kelompok & $M$ & $S D$ & $t$ & $p$ \\
\hline Manajemen & Perempuan & 73,67 & 5,61 & 2,02 & 0,04 \\
konflik & Laki-laki & 71,73 & 7,15 & & \\
perkawinan & & & & & \\
\hline
\end{tabular}

\section{Diskusi}

Hasil analisis uji beda dengan menggunakan $t$ test two independent sample menunjukkan bahwa terdapat perbedaan yang signifikan antara manajemen konflik rumah tangga yang dimiliki kelompok laki-laki dan perempuan. Secara umum penelitian yang menyimpulkan bahwa gaya manajemen perempuan berbeda dengan laki-laki. (Sari \& Widyastuti, 2015; Wirawan, 2010). Sari dan Widyastuti (2015) menyebutkan perbedaan secara anatomis dan fisiologis menyebabkan perbedaan pula pada pola tingkah laku perempuan dan struktur aktivitas laki-laki. Beberapa faktor yang memengaruhi 
manajemen konflik atau pengelolaan konflik antara lain faktor situasional dan faktor pribadi. Faktor pribadi salah satunya dipengaruhi oleh jenis kelamin atau gender. Temuan ini didukung pula oleh hasil riset literatur psikologis kognitif menyatakan bahwa gender menjadi salah satu faktor level individual yang dapat berpengaruh terhadap kinerja yang memerlukan judgment dalam berbagai kompleksitas tugas (Pasanda \& Paranoan, 2013).

Sedangkan hasil penelitian berdasarkan perbedaan mean antara kelompok laki-laki dan perempuan ini ditemukan bahwa manajemen konflik kelompok perempuan mempunyai skor lebih tinggi daripada manajemen konflik kelompok laki-laki. Berarti dari acuan tersebut dapat dikatakan bahwa perempuan mempunyai kemampuan manajemen konflik perkawinan lebih baik daripada laki-laki. Penelitian yang mendukung temuan ini antara lain penelitian Sumalata, Byadgi, \& Yadav, 2013) yang menemukan bahwa perempuan atau istri memiliki manajemen konflik akomodasi yang dinilai lebih baik daripada manajemen konflik yang digunakan oleh laki-laki yaitu gaya kolaborasi dan penghindaran. Serta didukung oleh penelitian Bogda dan Sendil (2012) secara tidak langsung mengemukakan bahwa perempuan memiliki kecenderungan melakukan manajemen konflik yang baik dan aktif dibandingkan laki-laki dan laki-laki cenderung menggunakan manajemen yang negatif dibuktikan dengan cenderung berperilaku menghindar saat menghadapi permasalahan yang terjadi.

Temuan pada penelitian ini bertolak belakang dengan penelitian manajemen konflik secara umum. Hal ini terkait dengan pengertian kemampuan manajemen konflik. Menurut Nugraha dan Januarti (2015) pengertian kemampuan manajemen yang sukses yang pada umumnya lebih dimiliki laki-laki yang didasarkan pandangan Sex Role Stereotypes tentang laki-laki yang dipandang lebih berorientasi pada pekerjaan, mampu bersikap obyektif, independen, dan pada umumnya mempunyai kemampuan yang lebih dalam pekerjaan. Sedangkan wanita dipandang lebih pasif dan memiliki orientasi pertimbangan lebih rendah dibandingkan laki-laki dalam organisasi.

Penelitian Nugraha dan Januarti (2015) ini juga didukung oleh pernyataan Eaghly (1987) dalam Trianevant (2014) yang menyatakan bahwa laki-laki lebih berorientasi pada pekerjaan, objektif, independen, agresif, dan pada umumnya mempunyai kemampuan lebih dibandingkan perempuan dalam pertanggungjawaban manajerial, termasuk pada manajemen yang dimiliki dalam rumah tangga. Dalam lingkungan pekerjaan pun, apabila terjadi masalah atau konflik dalam pekerjaan, pegawai laki-laki akan merasa tertantang menghadapinya dibandingkan untuk menghindarinya. Sedangkan pegawai perempuan akan cenderung untuk menghindari konsekuensi konflik dibanding perilaku pegawai lakilaki, meskipun dalam banyak situasi perempuan lebih banyak melakukan kerja sama dibanding laki-laki, tetapi apabila akan ada risiko timbul, laki-laki cenderung lebih banyak membantu dibanding perempuan (Eaghly, 1987 dalam Trianevant, 2014).

Sedangkan temuan penelitian manajemen konflik dalam rumah tangga, penelitian yang bertolak belakang dengan temuan penelitian ini salah satunya pernyataan Delatorre dan Wagner (2018) yang menyebutkan strategi manajemen yang dilakukan oleh kelompok laki-laki kebanyakan memakai kompromi, sedangkan perempuan lebih sering menggunakan manajemen konflik "attack" atau menyerang. Hal ini didukung oleh temuan penelitian Coyne dkk. (2017) yang menyebutkan perempuan menggunakan agresi lebih banyak daripada laki-laki dalam hubungan pernikahan.

Hasil penelitian yang bertolak belakang di atas salah satunya menjelaskan bahwa strategi manajemen konflik laki-laki lebih baik, tetapi walaupun laki-laki lebih sering menggunakan manajemen konflik kompromi (yang dinilai positif), tapi jika ditelisik lebih jauh laki-laki ternyata juga cenderung melakukan pertahanan dan menghindar dalam menghadapi konflik (Delatorre \& Wagner, 2018; Kiecolt-Glaser \& Newton, 2001; Gbadamosi dkk., 2014).

Manajemen konflik perempuan berdasarkan penelitian ini dinilai lebih baik daripada laki-laki jika ditinjau dari beberapa aspek, salah satunya adalah kemampuan dalam menganalisis konflik yang terjadi (Pruit \& Rubin, 2009). Penelitian menyebutkan perempuan lebih efisien dan efektif dalam memproses informasi dalam tugas yang kompleks dibanding laki-laki karena perempuan lebih memiliki kemampuan untuk membedakan dan mengintegrasikan kunci keputusan. Laki-laki relatif kurang mendalam dalam menganalisis inti dari suatu keputusan (Chung \& Monroe, 2001). Hal ini didukung oleh penemuan Fitriani (2013) yaitu perempuan lebih bersifat menyeluruh atau komprehensif dalam memproses informasi dibandingkan laki-laki.

Selain kemampuan dalam menganalisis konflik, kemampuan melakukan kompromi (Pruit \& Rubin, 2009) yang dimiliki perempuan juga dinilai lebih baik daripada laki-laki. Bila konflik terjadi di antara lakilaki, mereka cenderung menggunakan ancaman dan kekerasan, sedangkan anak perempuan cenderung menggunakan strategi yang melunakkan konflik (Phutallaz \& Sheppard dalam Mardianto, Koentjoro \& Purnamaningsih, 2000). Dalam konflik, wanita menginginkan kerja sama dari suami dan pria menginginkan otonomi. Wanita mengidentifikasi lebih banyak masalah dalam suatu hubungan daripada pria (Dildar \& Amjad, 2017). Kerjasama individu dalam menangani konflik rumah tangga diharapkan dapat mengurangi efek dari konflik rumah tangga itu sendiri (Zhou \& Buehler, 2017).

Terakhir, menurut manajemen konflik Pruit dan Rubin (2009), aspek yang mendukung baik atau tidaknya manajemen konflik yang dilakukan individu dipengaruhi oleh kemampuan individu dalam melihat seutuhnya konflik yang terjadi. Dalam hasil penelitian ini, perempuan dinilai lebih mampu melihat seutuhnya konflik yang terjadi karena perempuan 
mahir dalam membaca sinyal emosi baik verbal dan non verbal dan mengungkapkan perasaannya (Goleman, 1999). Hal ini didukung pula oleh penelitian Berrocal, Cabello, Castilo, dan Extrema, (2012) tentang perbedaan gender dalam aspek emosi yang menyatakan bahwa perempuan lebih dapat memahami informasi emosi nonverbal. Hal ini dikarenakan perempuan lebih familiar dengan dunia emosi daripada laki-laki.

Selain faktor gender, faktor lain yang berkaitan dengan perbedaan manajemen konflik yang dimiliki masing-masing pasangan yaitu faktor peran sosial sesuai gender (Gbadamosi dkk., 2014), sisi perkembangan individu (Keener \& Strough, 2017) dan juga faktor lain seperti religiositas dan lamanya menjalin hubungan (Delatorre \& Wagner, 2018; Kamp Dush \& Taylor, 2012).

Studi menemukan baik pria ataupun wanita cenderung menggunakan strategi manajemen konflik sesuai peran gender yang diharapkan (Gbadamosi dkk., 2014). Stereotip pada gender diasosiasikan dengan laki-laki dan perempuan tidak hanya berbeda tetapi juga di inginkan secara berbeda (Sabrina, Ratnawati, \& Setyowati, 2016). Secara peran sosial, wanita lebih dominan dalam melakukan tugas rumah tangga, perbedaan peran ini membuat perbedaan pula dalam manajemen konflik yang digunakan (Delatorre \& Wagner, 2018; Kiecolt-Glaser dan Newton, 2001).

Temuan Wheeler, Updegraff, dan Thayer (2010) yang melakukan penelitian 227 pasangan di Meksiko, menemukan bahwa resolusi atau manajemen konflik dipengaruhi oleh orientasi budayanya. Di Indonesia, budaya patriarki membuat peran perempuan sebagai "makhluk manusia kedua" yang mempunyai peran sosial yang bertanggung jawab pada tugas domestik, belum lagi perempuan yang bekerja dituntut untuk menempatkan peran domestik dan perkerjaan sama penting sehingga menimbulkan "peran ganda" (Ahdiyah, 2013). Sehingga perempuan terbiasa melakukan dua pekerjaan tersebut sekaligus yang membutuhkan manajemen konflik yang baik. Sebaliknya, bagi lakilaki pekerja, tidak ada istilah "beban ganda", mereka pada umumnya memang tidak bekerja ganda karena mereka tidak dituntut untuk menyelesaikan tugastugas rumah tangga, sebagaimana halnya perempuan (Fakih, 1999).

Selain faktor peran sosial terhadap gender, perkembangan sosial juga memengaruhi manajemen konflik rumah tangga yang dimiliki individu. Pada masa perkembangan sosial masa anak-anak, strategi yang dipakai laki-laki cenderung hanya efektif dipakai jika mereka berinteraksi dengan sesama jenis atau teman sepermainan dibandingkan dengan lawan jenis, itulah kenapa jika berurusan dengan lawan jenis, laki-laki cenderung menggunakan strategi menghindar dalam menghadapi konflik untuk mengurangi stress (Keener \& Strough, 2017). Phutallaz dan Sheppard (dalam Mardianto dkk., 2000) menjelaskan bahwa perbedaan manajemen konflik tercermin dalam perilaku konflik pada masa anak-anak. Anak perempuan cenderung untuk mempertahankan interaksi yang harmonis, sedangkan anak laki-laki tampak lebih menaruh perhatian terhadap kekuasaan dan status selama berinteraksi dengan anak yang lain. Pernyataan tersebut diperkuat dengan pernyataan yang menyebutkan bahwa perempuan dalam perbedaan peran dan perkembangan sosial lebih mempertimbangkan pengaruh tindakan mereka pada orang lain dari pada laki-laki (Straughan \& Robert, 1999 dalam Junaedi, 2008). Dari segi perkembangan moral pun, Barbara (dalam Pasanda \& Paranoan, 2013) mengindikasikan bahwa pertimbangan moral dan alasan mendasar dalam etika pada pria dan wanita berbeda, wanita memiliki pertimbangan moral yang lebih tinggi dibandingkan dengan pria.

Faktor lain yang memengaruhi manajemen konflik individu adalah religiositas dan lamanya menjalin hubungan. Religiositas berhubungan dengan frekuensi dalam berkonflik, dan manajemen konflik yang positif atau konstruktif (Delatorre \& Wagner, 2018). Pasangan dengan religiositas tinggi lebih mampu beradaptasi dan bekerjasama saat menghadapi konflik dibandingkan dengan yang religiositasnya rendah (Kamp Dush \& Taylor, 2012). Selanjutnya pasangan yang menjalin hubungan lebih lama dan usia lebih dewasa cenderung lebih sedikit menghadapi konflik, kalaupun ada hanyalah konflik dengan level kecil. Hal ini dikarenakan mereka mempunyai makna pernikahan yang lebih sakral dan dukungan sosial untuk mempertahankan pernikahan yang terbentuk melalui lingkungan sosial turut membantu dalam menjaga hubungan pernikahan mereka (Kamp Dush \& Taylor, 2012).

\section{Kesimpulan}

Manajemen konflik rumah tangga berbeda jika ditinjau dari gender. Perempuan lebih tangkas dalam mengelola konflik pernikahan daripada laki-laki. Perempuan dinilai mempunyai kemampuan yang lebih dalam melihat seutuhnya konflik yang terjadi menurut situasi yang terjadi, kemampuan menganalisis konflik dan kompromi dengan pasangan bila di banding dengan laki-laki. Berdasarkan hasil penelitian dengan menggunakan diketahui terdapat perbedaan manajemen konflik yang signifikan antara perempuan, di mana skor manajemen konflik kelompok perempuan lebih besar dari skor manajemen konflik kelompok laki-laki.

Berdasarkan acuan tersebut dapat dikatakan bahwa perempuan mempunyai kemampuan manajemen konflik rumah tangga lebih baik daripada laki-laki. Aspek yang menjadi faktor perempuan memiliki kemampuan manajemen konflik rumah tangga yang lebih baik dapat dilihat dari kemampuan perempuan dalam melihat konflik yang terjadi, menganalisis konflik serta kemampuan kompromi. Sedangkan faktor lain yang mungkin memengaruhi adalah peran sosial sesuai gender, segi 
perkembangan sosial, religiositas, serta lamanya menjalin hubungan.

\section{Keterbatasan dan Saran}

Keterbatasan penelitian ini ada pada alat ukur yang digunakan hanya dapat mendeskripsikan perbandingan manajemen konflik perkawinan pada suami dan istri tidak secara spesifik menggunakan jenis manajemen konflik yang kebanyakan digunakan suami dan istri dalam menghadapi konflik rumah tangga. Saran untuk peneliti selanjutnya agar membagi manajemen konflik berdasarkan jenis manajemen konflik yang digunakan oleh pasangan suami istri. Selain itu, penelitian selanjutnya dapat juga mencoba memahami peranan faktor individual lainnya, seperti tingkat pendidikan, lama menjalin hubungan sebelum menikah, serta perbedaan kepribadian.

\section{Daftar Pustaka}

Ahdiyah, I. (2013). Peran-peran perempuan dalam masyarakat. Jurnal Academica. 5 (2), 10851092. Diunduh

dari http://jurnal.untad.ac.id/jurnal/index.php/ac ademica/article/view/2247

Astuti, E. M. (2009). Hubungan antara kematangan emosi dan jenis kelamin dengan agresivitas pada komunitas slankers. (Skripsi tidak diterbitkan). Surakarta: Fakultas Psikologi Universitas Muhammadiyah Surakarta.

Bear, J. B., Weingart, L. R., \& Todorova, G. (2014). Gender and the emotional experience of relationship conflict: The differential effectiveness of avoidant conflict management. Negotiation and Conflict Management Research, 7(4), 213-231. doi: 10.1111/ncmr.12039

Berrocal, P. F., Cabello, R., Castilo, R., Extrema, N. (2012). Gender differences in emotional intelligence: the mediating effect of age. Behavioral Psychology/Psicologia Conductual. 20(1), 77-89. Retrieved from http://jornadasaludemociongenero.uji.es/wpcontent/uploads/2014/11/FernandezBerrocal.pdf

Brahnam, S. D., Margavio, T. M., Hignite, M. A., Barrier, T. B., \& Chin, J. M. (2005). A gender-based categorization for conflict resolution. Journal of Management Development, 24(3), 197-208. doi: $10.1108 / 02621710510584026$

Bogda, D. K., dan Sendil, G. (2012). Investigating infidelity tendency and conflict manajement based on attachment style and gender. Journal of Sosial Sciences. 11(40), 205-219. Retrieved from

http://dergipark.gov.tr/download/articlefile/70369

Coyne, S. M., Nelson, D. A., Carroll, J. S., Smith, N. J., Yang, C., Holmgren, H. G., \& Johnson, C. (2017). Relational aggression and marital quality: A five-year longitudinal study. Journal of Family
Psychology, 31(3), 282-293. doi: $10.1037 /$ fam 0000274

Chung, J. dan G. S. Monroe. (2001). A research note on the effect of gender and task complexity on audit judgment. Behavioral Research in Accounting. 13(1), 111-125. doi: 10.2308/bria.2001.13.1.111

DeChurch, L. A., Mesmer-Magnus, J. R., \& Doty, D. (2013). Moving beyond relationship and task conflict: Toward a process-state perspective. Journal of Applied Psychology, 98, 559-578. doi:10.1037/a0032896

Delatorre, M. Z., \& Wagner, A. (2018). Marital conflict manajement of married men and women. Psico-USF. 23(2), 229-240. doi: 10.1590/141382712018230204

Dewi, N., R., \& Sudhana, H. (2013). Hubungan antara komunikasi interpersonal pasutri dengan keharmonisan dalam pernikahan. Jurnal Psikologi Udayana. 1(1), 22-31. Diunduh dari https://ojs.unud.ac.id/index.php/psikologi/ar ticle/view/25045/16261

Dildar, S., \& Amjad, N. (2017). Gender differences in conflict resolution styles (CRS) in different roles: A systematic review. Pakistan Journal of Sosial and Clinical Psychology, 15(2), 37-41. Diunduh dari http://www.gcu.edu.pk/FullTextJour/PJSCS/ 2017b/6.Saadia\%20Dildar,\%20Final\%20revi ewed\%20article,\%20systematic\%20review,\% 208th\%20february,\%202018.pdf

Dildar, S., Bashir, S., Shoaib, M. Sultan, T., Saeed, Y. (2012). Chains do not hold a mariage together: emotional intelligence and marital adjustmen (a case of Gujrat district, Pakistan). Middle-East Journal of Scientific Research. 11 (7), 982-987. Diunduh dari https://www.researchgate.net/publication/2 75888835_Chains_Do_Not_Hold_a_Marriage_T ogether_Emotional_Intelligence_and_Marital_ Adjustment_A_Case_of_Gujrat_District_Pakista $\mathrm{n}$

Doss, B. D., Rhoades, G. K., Stanley, S. M., \& Markman, H. J. (2009). Marital therapy, retreats, and books: The who, what, when, and why of relationship help-seeking. Journal of Marital and Family Therapy, 35(1), 18-29. doi:10.1111/j.1752-0606.2008.00093.x

Fakih, M. (1999), Analisis gender dan transformasi sosial. Yogyakarta: Pustaka Pelajar.

Fitriyani, M. (2013). Pengaruh gender, tekanan ketaatan, kompleksitas tugas dan pengalaman auditor terhadap audit judgment. (Skripsi tidak di terbitkan). Surakarta: Fakultas Ekonomi dan Bisnis Universitas Muhammadiyah Surakarta.

Gbadamosi, O., Ghanbari Baghestan, A., \& Al-Mabrouk, K. (2014). Gender, age and nationality: Assessing their impact on conflict resolution styles. Journal of Manajement Development, 33(3), 245-257. doi: 10.1108/JMD-02-20110024 
Greeff, A. P. \& de Bruyne, T. (2000). Conflict management style and marital satisfaction. Journal of Sex and Marital Therapy. 26(4), 321334. doi:10.1080/009262300438724

Goleman, D. (1999). Emotional Intelligence. Jakarta: Gramedia Pustaka Utama.

Hapsari, E. (2013, 28 November). Usia pernikahan kurang dari 5 tahun rawan cerai?. diunduh dari https://www.republika.co.id/berita/humaira /samara/13/11/27/mwx7mx-usiapernikahan-kurang-dari-5-tahun-rawan-cerai

Hidayat, R. (2018, 18 Juni). Melihat tren perceraian dan dominasi penyebabnya. Diunduh dari https://www.hukumonline.com/berita/baca/ lt5b1fb923cb04f/melihat-tren-perceraiandan-dominasi-penyebabnya

Hurlock. E. B. (1980). Psikologi perkembangan: suatu pendekatan sepanjang rentang kehidupan. Jakarta: Penerbit Erlangga.

Junaedi, M. F. S. (2008). Pengaruh gender sebagai pemoderasi pengembangan model perilaku konsumen hijau Di Indonesia. KINERJA. 12(1), 17-37. doi: 10.24002/kinerja.v12i1.1388

Kamp Dush, C. M., \& Taylor, M. G. (2012). Trajectories of marital conflict across the life course: Predictors and interactions with marital happiness trajectories. Journal of Family Issues, 33(3), 341-368. doi: 10.1177/0192513X11409684

Keener, E., \& Strough, J. (2017). Having and doing gender: Young adults' expression of gender when resolving conflicts with friends and romantic partners. Sex Roles, 76(9-10), 615626. doi:10.1007/s11199-016-0644-8

Kiecolt-Glaser, J. K., \& Newton, T. L. (2001). Marriage and health: His and hers. Psychological Bulletin, 127(4), 472-503. doi: 10.1037//00332909.127.4.472

Mardianto, A., Koentjoro., \& Purnamaningsih, E. H. (2000). Penggunaan manajemen konflik ditinjau dari status keikutsertaan dalam mengikuti kegiatan pecinta alam di Universitas Gadjah Mada Yogyakarta. Jurnal Psikologi. 27(2), 111-119. doi: 10.22146/jpsi.7003

Muharajah, K. (2018). Akibat hukum perceraian bagi anak dan istri yang disebabkan oleh kekerasan dalam rumah tangga: Studi kasus di pengadilan tinggi agama Semarang. SAWWA. 12(3), 337356. doi: $10.21580 /$ sa.v12i3.2092

Muhibar, A. (2016, 17 November). 3 provinsi ini sumbang angka perceraian tertinggi di Indonesia. Liputan6. Diunduh dari https://www.liputan6.com/lifestyle/read/26 54865/3-provinsi-ini-sumbang-angkaperceraian-tertinggi-di-indonesia

Muhyiddin. (2018, 21 Januari). Ratusan ribu kasus perseraian terjadi dalam setahun. Republika. Diunduh dari https://www.republika.co.id/berita/duniaislam/islamnusantara/18/01/21/p2w4v9396-ratusanribu-kasus-perceraian-terjadi-dalam-setahun
Nugraha, A. P., \& Januarti, I. (2015). Pengaruh gender, pengalaman, keahlian auditor dan tekanan ketaatan terhadap audit judgment dengan kompleksitas tugas sebagai variabel moderasi pada BPK RI Jawa Tengah. (Skripsi tidak diterbitkan). Semarang: Fakultas Ekonomika dan Bisnis Universitas Diponegoro.

Nurcahyanti, F. W. (2010). Manajemen konflik rumah tangga. Yogyakarta: Insania.

Nurhasanah, N. (2017). The analysis of causes of divorce by wives. The International Journal of Counseling And Education. 2(4), 192-200. doi: 10.23916/002017027240

Pasanda, E., \& Paranoan, N. (2013). Pengaruh gender dan pengalaman audit terhadap audit judgment. Jurnal Akuntansi Multiparadigma (JAMAL). 4(3), 330-507. doi: 10.18202/jamal.2013.12.7207

Pruitt, D. G. \& Rubin, J. Z. (2009). Teori konflik sosial. Yogyakarta: Pustaka Pelajar.

Pudjiastuti, E., \& Santi, M. (2012). Hubungan antara asertivitas dengan penyesuaian perkawinan pasangan suami istri dalam usia perkawinan 15 tahun di Kecamatan Coblong Bandung. Prosiding SNaPP2012: Sosial, Ekonomi, dan Humaniora. 3(1), 9-16. Diunduh dari http://proceeding.unisba.ac.id/index.php/sos ial/article/view/85

Rachmadani, C. (2013). Strategi komunikasi dalam mengatasi konflik rumah tangga mengenai perbedaan tingkat penghasilan di RT. 29 Samarinda Seberang. eJournal Ilmu Komunikasi. 1(1), 212-227. Diunduh dari http://ejournal.ilkom.fisipunmul.ac.id/site/wpcontent/uploads/2013/03/JURNAL\%20ILMI AH\%20CHERNI\%20RACHMADANI\%20(0311-13-10-00-17).pdf

Sabrina, T., Ratnawati, R., \& Setyowati, E. (2016). Pengaruh Peran Gender, Masculine Dan Feminine Gender Role Stress Pada Tenaga Administrasi Universitas Brawijaya. IJWS. 4(1) 1-14. Diunduh dari https://ijws.ub.ac.id/index.php/ijws/article/ view/111

Saidiah, S., \& Julianto, V. (2016). Problem pernikahan dan strategi penyelesaiannya: studi kasus pada pasangan suami istri dengan usia perkawinan dibawah sepuluh tahun. Jurnal Psikologi Undip. 15(2), 124-133. doi: 10.14710/jpu.15.2.124133

Sari, T. D., \& Widyastuti, A. (2015). Hubungan antara kecerdasan emosi dengan kemampuan manajemen konflik pada istri. Jurnal Psikologi. 11(1), 49-54. doi: 10.24014/jp.v11i1.1433

Santrock, J. W. (2012). Adolescence : Fourteenth edition. New York : Mc Graw Hill.

Sumalata., Byadgi. T. S., \& Yadav. V. (2013). Conflict Resolution Strategies Among Working Couples. IOSR Journal Of Humanities and Sosial Science. 14(4), 31-37. Retrieved from 
http://www.iosrjournals.org/iosrjhss/papers/Vol14-issue4/E01443137.pdf

Takariawan, C. (2015, 17 Juni). Di Indonesia, 40 perceraian setiap jam. Kompasiana. Diunduh dari http://www.kompasiana.com/pakcah/diindonesia-40-perceraian-setiapjam_54f357c07455137a2b6c7115

Trianevant, M. (2014). Pengaruh gender, orientasi tujuan, self efficacy, dan pengalaman terhadap audit judgement. (Skripsi tidak diterbitkan). Bandung: Fakultas Ekonomi Universitas Widyatama.

Wheeler, L. A., Updegraff, K. A., \& Thayer, S. M. (2010). Conflict resolution in mexican-origin couples: culture, gender, and marital quality. Journal of Marriage and Family. 72(4), 991-1005. doi: 10.1111/j.1741-3737.2010.00744.x
Wirawan. (2010). Konflik dan manajemen konflik. Jakarta: Salemba Humanika.

Yasmine. (2017, 5 November). Hati-hati, ini usia rawan pernikahan dan penyebab perceraian. Diunduh dari https://www.liputan6.com/health/read/315 1866/hati-hati-ini-usia-rawan-pernikahandan-penyebab-perceraian

Zhou, N., \& Buehler, C. (2017). Adolescents' responses to marital conflict: The role of cooperative marital conflict. Journal of Family Psychology : JFP : Journal of the Division of Family Psychology of the American Psychological Association (Division 43), 31(7), 910-921. doi: $10.1037 /$ fam 0000341 


\section{Lampiran A}

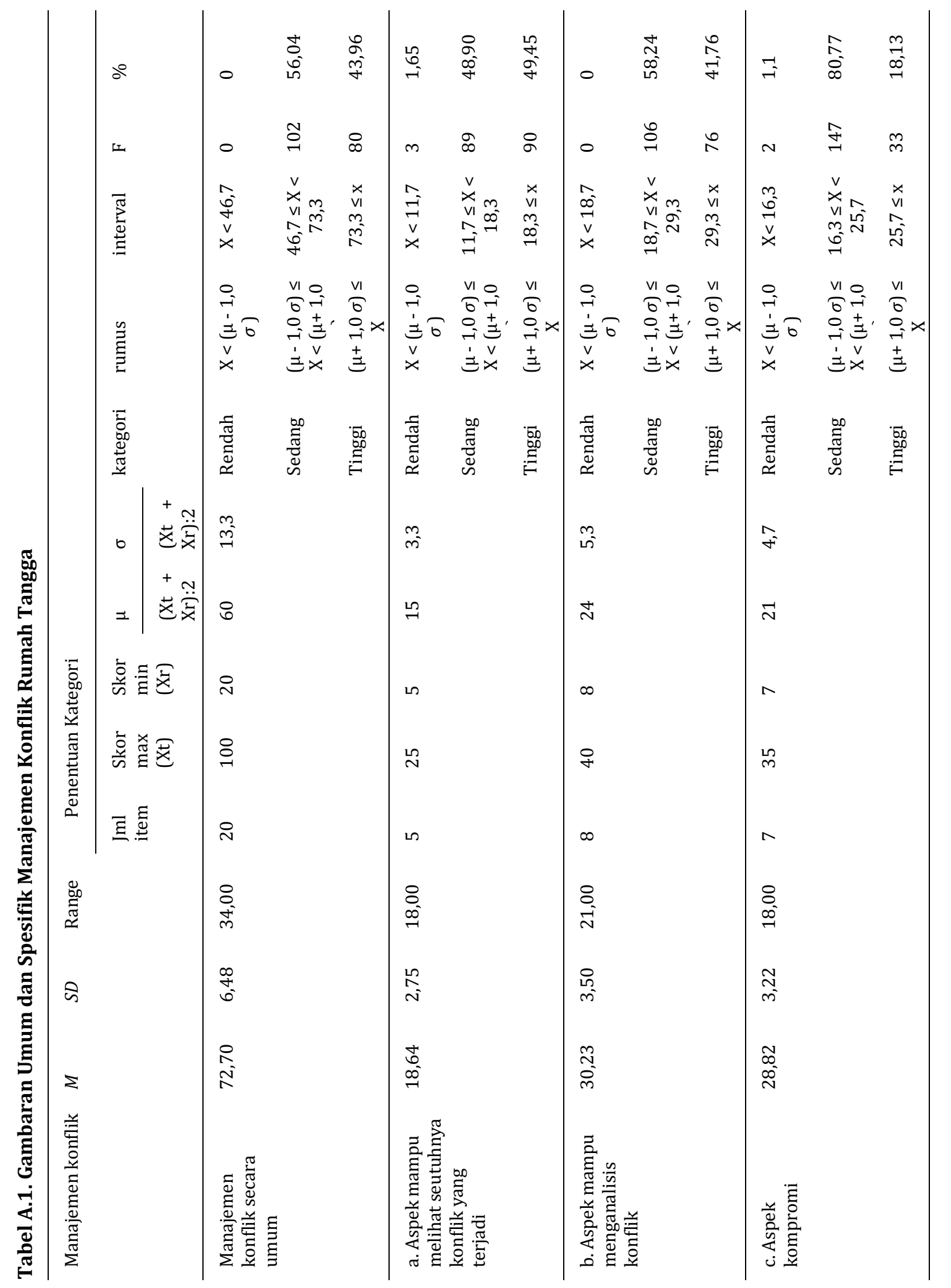

